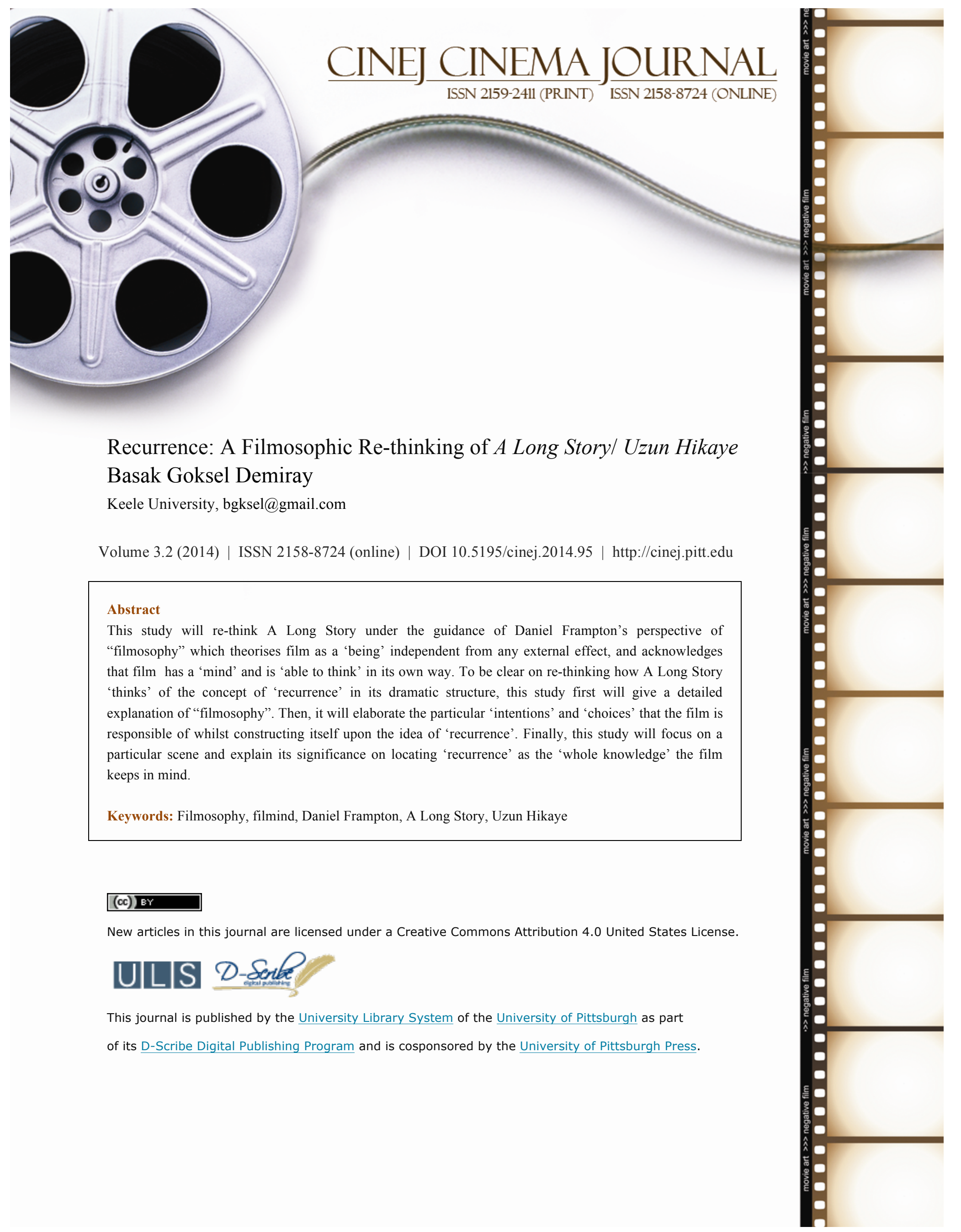




\section{Recurrence: A Filmosophic Re-thinking of A Long Story/ Uzun Hikaye Basak Goksel Demiray}

It is very hard to tell such a long story. It is as long as the duration of a film, but as short as a couple of lives. (Mustafa, A Long Story)

In this study, Daniel Frampton's conception of Filmosophy will be the guide to re-think the film named A Long Story (Uzun Hikaye, Osman Sinav ${ }^{1}$, 2012, Turkey). For Frampton, a film already thinks in its own way, unlike and "beyond" ours (Frampton 2006, p. 92). Thus, by taking its departure from the filmosophical perspective, this study prefers 're-thinking' a film instead of 'reading', 'interpreting', 'analysing' or 're/framing' it.

Filmosophic re-thinking demands from the 'filmosopher" ${ }^{2}$, that a film must be re-thought independently, with no reference to its creator, other films, theories or technics. Hence, this study should be taken into consideration, as it is the consequence of the "first-time naive experience" of its author (me/filmosopher) of a single film, namely A Long Story (Frampton 2006, p. 31). In this manner, the aim of the study is to give the idea that re-thinking the foregoing film will be away from any other thought, definition or intention external to the film.

To reach this aim, this study first will give a detailed explanation of Frampton's conception of Filmosophy. Then, in light of this conception and by particular 'intentions and choices' immanent to the film - coming from nowhere or nobody outside - it will explain how $A$ Long Story itself 'thinks' the concept of 'recurrence' in its dramatic structure. Finally, this study will focus on a particular scene ${ }^{3}$ and explain the significance of how this scene functions to locate the abovementioned concept of 'recurrence' into the entire film. 


\section{Filmosophy}

In his book named Filmosophy (2006), Daniel Frampton tries to find a new kind of theorisation regarding films. He positions himself against four ongoing attitudes in existing film studies: 1) "director-based writing", 2) "theorising [films] via human thinking" and "human-like terms", 3) "ultimate" separation of form and content in theories of narration, and 4) "overwhelming" employment of technical terminology in film writings (Frampton 2006, p. 30, $31,46,114,173)$.

According to Frampton, the first and the most important step of filmosophic re-thinking of a film is staying away from the fact of the existence of its creator. At this point, - on the contrary of auteurist theories ${ }^{4}$ that explain any single shot in a film with its creator's intentions and his/her consciously or unconsciously made choices - filmosophy argues that film is a 'being' which has its own mind and its own way of thinking (Frampton 2006, p. 73). Thus, Frampton builds his theorisation upon the concepts of 'filmind' and 'film-thinking' and defends that the only being that is responsible of the intentionality and the choices inherent in the film is the film itself. Whilst constructing his theorisation like this, Frampton also reminds "filmosophy does not aim to side-line the creators of cinema, but simply attempts to re-invigorate the experience of film." (Frampton 2006, p. 75)

In his foregoing reminder, there is an emphasis on the encounter ${ }^{5}$ of a film and a filmgoer because Frampton attaches a big importance to filmgoer's activity of thinking solely the film whilst watching it. For him, a filmgoer does not need to (should not) think about the "external invisible puppeteer" (i.e. creator/ director), his/her intentions and choices, used technology and conditions of production with its pre and post processes (Frampton 2006, p. 99). That is to say, in

CINEJ Cinema Journal: Recurrence: A Filmosophic Re-thinking of A Long Story/Uzun Hikaye

Volume 3.2 (2014) | ISSN 2158-8724 (online) | DOI 10.5195/cinej.2014.95 | http://cinej.pitt.edu 
Frampton's filmosophic perspective, whatever external to the film is "not significant to the filmgoer ${ }^{6,}$ s experience." (ibid)

Theorising a film as a 'being', responsible of its actions deriving from its own intentions and choices, inherently attributes it a 'mind' and an 'ability of thinking'. However, Frampton distinguishes filmind and film's abilities from the ones humans have. He mainly thinks that filmind works beyond how human minds work because filmind has the "knowledge of the whole" (Frampton 2006, p. 84). It knows what will happen both at the beginning and at the end of the film and constructs its world thanks to this knowledge. On the contrary, human mind is not capable of having the knowledge of the whole and no human is able to know his/her end. In this sense, Frampton finds human mind limited and also he quotes Noel Carrol and agrees with him that it is hard to explain the thinking of a film in relation to the thinking of a human mind "because we do not know enough about how the [human] mind itself works." (Frampton 2006, p. 91) That is the point what makes Frampton stand against the theorisation of films via human thinking coming from outside the film and see this attitude as a "dead end" in film studies (Frampton 2006, p. 31).

Thus, he recommends a new kind of theorisation arising solely from a 'film-being ${ }^{7}$ ' and accepts the nature of this 'being' as "non-human-like" (Frampton 2006, p. 46). The examples Frampton gives, support his argument effectively as follows:

When I am in love with someone they do not always appear to me in soft-focus. When I am envious of another, or feeling sick, the world does not turn green suddenly. Desire does not cloud my vision in a red haze. We cannot see in black and white, nor actually 'zoom in' on things. (Frampton 2006, p. 47)

The abovementioned examples put emphasis on film's ability to think itself through form. As film has the knowledge of the whole, it constructs its dramatic structure by making its formal 
choices in correlation with the demands of its world. In each step, film knows what to show us and how to show it to us. Each film has its own attitude of showing its characters, objects and locations which are inherent in the life flowing through the whole film.

As stated before, film is responsible of its own intentions and choices of the life it creates. Whilst creating the kind of life, about which it has the whole knowledge, a film chooses its own time, location, characters, objects, clothing, events, languages, narrator and so on, concurrently with their colours, sounds, music, sizes, movements, distances, timings and so on. That is to say, it is a process of creation of the 'whole', not separate parts. Thus, ultimate separation of form and content, like narration theories always do, is one of the attitudes that Frampton resists regarding the existing film studies. According to him, "we (should) respond to the whole caboodle: we cannot see what is 'in' the film without seeing it the way the film thinks it." (Frampton 2006, p.

Originating from such a 'mind' which has the knowledge of its own 'end', every single thing in a film becomes thought and intended. In this case, form and content are non-separable from each other since they are thought and intended at the same time by the filmind. From its beginning to the end, a film thinks concurrently about the answers of the questions of 'what' and 'how' and creates itself as a whole 'being' which 'controls the narrative and any narrators, but also importantly designs the images and sounds of the film-world." (ibid) This kind of mind provides a film with the integrity by balancing the significance of form and content in its life. Thus, Frampton finds it necessary to construct his conception of filmosophy via such a balancing attitude, which, in his view, also should be embraced by other theorisations in film studies.

In the meantime, he draws attention to the crucial role of a filmgoer regarding the construction of such a balance in both his own theorisation and other existing film studies. From

CINEJ Cinema Journal: Recurrence: A Filmosophic Re-thinking of A Long Story/Uzun Hikaye 
the filmosophical perspective, "[s]eeing film as 'thinking' ties content, form and filmgoer together, $[\ldots]$ " because the filmgoer is the one who is able to perceive and feel the film's 'thinking' as an integral process. (Frampton 2006, p. 212) Frampton attaches a big importance to the experience of a filmgoer and believes that there is an affective relation between him/her and a film. He explains the act of a filmgoer as 'feeling' the film more than seeing and hearing it and employs the concepts of "sensory thought" and "affective intelligence" to be clearer in his explanation of filmgoer's act. (Frampton 2006, p. 166) For filmosophy, during his/her experience of film, a filmgoer stays away from his/her daily life, sweeps into the film world and since filmthinking organicises the relation between form and content, s/he "see[s] film forms as dramatic rather than technical.” (Frampton 2006, p. 174)

For this reason, from the filmosophical point of view, Frampton finds the employment of technical terminology of film-making "useless" ${ }^{8}$ " in his theorisation (Frampton 2006, p. 173). He believes that cinema starts with technology, however since "the filmgoer does not see this mechanism; cranes, tracking shots, camera, and so forth, are in themselves not significant to filmgoer's experience.” (Frampton 2006, p. 99) Thus, he agrees with Vivian Sobchack and by quoting her, asks if we, as filmgoers, do not see the making of films "why should film writing relate to film as if it were 'some objective mechanism like a water heater'?" (ibid)

In fact, via the tone of the foregoing question, Frampton points out the tendency of film writers to employ technical terminology overwhelmingly in film writings. He stands against this attitude because he thinks that technicist descriptive terms limit the possibility of meanings, which filmgoers may grasp variously through form. Filmosophy handles the single experience of each filmgoer as unique and attaches importance to the meanings, which can be grasped differently by different filmgoers. Besides, each film is a unique creation of itself and has its own 
formal choices of expression. Thus, according to Frampton, attributing particular meanings to particular form is limiting and reductive. (Frampton 2006, p. 173) Each formal choice of a filmind must be taken into consideration in relation to a film's unique and integral meaning and they cannot be described by simple technical terms which make filmgoers to have determined (fixed) understandings of meaning. To express effectively the reason of his resistance to the abovementioned attitude of film writers, Frampton gives an example from one of the 'moments' of Goodfellas and explains the difference between regular and filmosophical descriptions of the 'moments' as follows:

the Ray Liotta and Robert De Niro characters are sitting in a dinner late on in the film, and the film does a (now classic) track-out while zooming-in action [(..)]. Now, a technicist or formalist description would talk exactly of this camera movement and take some delight in explaining (away) how it was done. We do not need to be told what the film is technically doing, we can see what it is doing. A regular film studies description [(...)] would perhaps talk of the 'director' giving us a 'formal metaphor' for the changing 'world' of the characters. This generalised form of description has been happily used by film studies for a long while. The writer then uses this basic description to build their interpretation of the film. A filmosophical description of this scene might go something like this: the filmind understands the change in the relationship of two characters, and thinks (feels) the twist in their world. The film shows us the enclosed world of these two men (by only framing them), and shows how this world is subverted one by thinking (through image form) the relationship between the men, and their relationship to the outside world. Of course the regular description and the filmosophical one may be revolving around similar meanings, but the filmosophical one, with its unifying of form and intention, leads to further possible interpretations. The uniting of form and content using the concept of film-thinking creates an integral whole for the filmgoer. (Frampton 2006, p. 100, 101)

In light with the most crucial points that Frampton constructed his theorisation upon and have been elaborated in this study so far, the foregoing example becomes more explanatory about the unnecessity of any exterior thought, description or intention in filmosophical re-thinking of 
films. In this case, from now on, this study will endeavour to re-think A Long Story within the scope of the principles that Daniel Frampton both put forward regarding his conception of 'filmosophy' and resisted regarding the existing theorisations in regular film studies.

\section{How A Long Story ${ }^{9}$ thinks of 'recurrence'?}

Since Filmosophy acknowledges film as a 'being' that is able to think and create itself through its own mind, from now on, I, as a filmosopher ${ }^{10}$, will re-think $A$ Long Story with no reference to any external effect. Besides, in this study, I will not let the film's intentions and choices be described with limited meanings that technical or human-like terms referring, rather I will re-think them as the unique moments that I 'felt' during my 'first-time naive experience' of $A$ Long Story.

Under the guidance of Frampton's theorisation, I can express explicitly that A Long Story thinks and creates its dramatic structure through the concept of 'recurrence'. Thanks to the whole/integral knowledge of itself, from the beginning, the film chooses recurring through its places, objects and characters and knows how to finish itself as if converting into the same film again. With respect to this, A Long Story establishes its world on a story, which is 'long' enough to recur between the lives of a father (Ali) and a growing son (Mustafa). To be clear on my filmosophical re-thinking about this film's way of recurring, I will elaborate its choices item by item in the following.

1) A Long Story thinks itself starting with an approaching steam train which is carrying the teller of the story, namely Mustafa and it is also carrying a prologue ${ }^{11}$ to the 'long story' which will start and recur during the film through that train - between the lives of father Ali and his growing son

Mustafa. 'The film ${ }^{12}$, opens itself and does not move. It just waits for the train to come closer and 
start the story. With the knowledge in its mind that Ali's son will have the same story his father had, the film, at its end, shows the same steam train again; and waits at exactly the same place (point) for it to approach the same town and bring eldest ${ }^{13}$ Mustafa and his love Ayla to the same old abandoned wagon (in which Ali, his wife Münire and their son Mustafa (youngest) used to live). In this sense, A Long Story thinks itself recurring through its places, objects and characters, but particularly through its choice to wait for the same train, at the same place, both at opening and at closing times of the world/life it creates as if it is a never-ending story.

2) A Long Story thinks itself recurring mostly through its choices on creation of its characters. It guarantees the recurrence by creating particular characters similar to each other - i.e. Ali and Mustafa, Münire and Ayla. The thought/choice of 'similarity' basically occurs in A Long Story's own mind intending to construct itself upon the 'recurring destinies ${ }^{14}$, of its characters as follows: both Münire and Ayla attend to girls' vocational school/course; both couples first meet each other at a bookshop; both couples keep their love secret because of the oppressive fathers (Münire's and Ayla's) and brothers (Münire’s)/cousin (Ayla’s) of the girls; both Münire and Ayla are imprisoned at home and not allowed to see their lovers; both couples get in touch by means of the letters hidden in books exchanged secretly; both Münire and Ayla are asked by Ali and Mustafa to leave home and elope to marry without their fathers' permission; both Münire and Ayla refuse their lovers when they are first asked to elope but then they are convinced by the courage and strong love their lovers have; and both the news of the events their elopes brought on are published by newspapers.

A Long Story constructs recurrence not only by the 'similar' choices it makes regarding the destinies of its characters, but also regarding the physical features of the female characters,

CINEJ Cinema Journal: Recurrence: A Filmosophic Re-thinking of A Long Story/Uzun Hikaye

Volume 3.2 (2014) | ISSN 2158-8724 (online) | DOI 10.5195/cinej.2014.95 | http://cinej.pitt.edu 
Münire and Ayla. The film thinks them looking like each other so that Ali and Mustafa can fall in love with the girls that have similar outside appearances. This also reveals that the film also intends to recur in Ali's and Mustafa's choices and admirations of their eternal mates with blonde, long and curly hair, eyes with similar colours (blue/green) and clothing in similar styles. As well as the similarity in their outside appearances, both Münire and Ayla think, decide, speak and behave like each other, since they are created as the characters of recurring destinies. They see their mates by looking through similar perspectives and describe them with the same word as "crazy"; speak meaningful as they are reading passages from books; react in the same way and even mention the same words when they encounter with the same situations. These kinds of similarities will be detailed through particular examples not only referring Münire and Ayla, but also Ali and Mustafa, in the following.

As the film, from its beginning, has the knowledge and intention of recurrence in its mind, it makes Mustafa growing up to the age that his father and mother 20 years ago eloped, meeting a kind of girl similar to his mother and confronting a destiny almost the same with his father's. Therefore, the film, in its dramatic structure, thinks Mustafa thinking, deciding, speaking and behaving like his father as follows: Mustafa describes Ayla with the same words, gestures and expressions of admiration Ali describes Münire that "she has a hair like lepiska (flaxen hair), a blonde, long and curly hair (using his fingers like pretending as if they are curling); Mustafa listens Ayla with the same admiration Ali listens Münire whilst she is speaking and thinks the same with his father and mentions the same words that "she speaks meaningful like reading a passage from a book"; Mustafa answers Ayla's question "Do you know the man?" about the chief conductor of the train arriving at the station in a small town namely Dogancay - abovementioned 
is the same question with the one Münire asks about the chief conductor when Ali, Münire and little Mustafa arrive Dogancay at the beginning of the film - with the same words that Ali answers Münire "No, we just met each other, but he is really a very good man."

Along with the foregoing examples of the same descriptions, expressions, questions and answers being repeated by particular characters, the film also can be said recurring in/through utterances, as well. Principally, A Long Story's choice of hearing the same utterances from distinct but recurring characters might be elaborated as a separate item, but I preferred to handle it in relation to the characteristics that the film attributes to the certain people it creates.

3) The main object through which A Long Story continues constructing itself upon the concept of 'recurrence' is the 'typewriter' which Ali finds broken, fixes and then cleans together with little Mustafa. Whilst creating its dramatic structure, the film thinks Ali doting upon that typewriter and writing memories, journals and newspaper columns with it everywhere even in a prison. When Ali realises that eldest Mustafa is interested in writing too, he gives the typewriter to his son so that he can write wherever he is. Mustafa resists the idea of keeping the typewriter apart from his father when he is in prison but Ali insists and says "there is something that I know and so, I want you to take it along". At this point, this is overtly the expression of the film's own which means that 'there is something that the film knows' and for this reason it thinks Mustafa taking along only the typewriter whilst eloping with Ayla and starting to write the 'long story' of his parents on the train approaching to Dogancay. In this way, as the film tells itself through the story of Mustafa's parents written by him on the typewriter, it also provides the recurrence with 
the idea in its mind that, that typewriter would have the same meaning/place in Mustafa's future life which is implied by the film to be the same with Ali's past.

4) Dogancay is the place through which A Long Story chooses to recur itself, as well. The film waits for the train to approach Dogancay bringing eldest Mustafa who is going to start writing ${ }^{15} /$ telling A Long Story - which is "as long as the duration of a film but as short as a couple of lifetimes" in his own words. The film shows eldest Mustafa alone at the beginning to introduce him as the teller $^{16}$ of the story the film creates. Then along with the story starting to be heard from Mustafa's voice, the film brings Ali, Münire and youngest Mustafa to a small town, Dogancay where they find an old and abandoned wagon in order to have an accommodation (away from both Münire's family and the problems Ali had because of his opposition to the established order existing in the place they previously lived). In parallel with the story heard from eldest Mustafa's voice, the film shows little Mustafa growing and moving from town to town with his father because of Ali's oppositional personality that prevents him from staying at the same place for a long time. At the end, the film thinks Mustafa growing up to the age of his parents' elope and doing the same with them - eloping with Ayla by a train from which he and Ayla get off at Dogancay station and go directly to the same old wagon - to have their own and same 'long story' to be recurred and written, as if the same film is about to begin again. With the knowledge of recurrence in its mind, the film brings Mustafa, Ayla and the typewriter to the same place because thinks itself starting again from where it seems to be ending.

\section{Moments of the Play\&Tale}


A Long Story creates itself as the moments of a story that is being witnessed and told by Mustafa from the beginning to the end. However, there is another story (backstory of Ali and Münire that they had before Mustafa's birth) and the film thinks it as if a kind of play\&tale which the little Mustafa watches\&listens from his father's genuine/leading and mother's supporting performances of enacting the past events. This backstory provides A Long Story with 'the moments' of a play\&tale that function as a kind of prologue to the recurring destinies of Ali and Mustafa. The film chooses a unique way to make little Mustafa impressed by his parents' backstory (i.e. feeling it deeply as if it is really happening in front of his eyes), and learn what to do when he has the same kind of destiny with his father. This is such a way that seems to be aimed as to impress little Mustafa via his parents' performances of enacting the crucial events of their past. However, in fact it is a unique way to impress the filmgoers, to make them sweep into the film and feel the 'idea of recurrence' that $A$ Long Story all the time keeps in mind as the whole knowledge it has about itself.

During the moments of the play\&tale of the prologue, the film shows Ali and Münire as if they are living the events happened in their backstory again whilst telling and enacting them to their son. In the meantime, little Mustafa watches them with admiration as if it is the first time they are playing the theatre play or telling the tale which indeed he persistently demands from them to perform again and again. Little Mustafa has each step of the backstory memorised in his mind, and feels it as a joined activity he interactively experiences. He imitates his father in action, keeps his breath, claps his hands, and screams as if he were a paperboy selling the newspaper on which the news of Münire and Ali's elope is published. The film thinks that what Mustafa experiences in this play as a little child, would happen to him in his destiny. This study re-thinks these 'moments' of the play\&tale as the prologue of A Long Story, as the precursor of the 
recurrence constructed intentionally in the entire film in various ways. Abovementioned moments are explained in their significance to understand the recurrence between lives of a father and a growing son, however there are some formal choices that the film made whilst being and living those moments itself. For instance, the film makes the filmgoer to hear the real voices and sounds of those past events whilst being told and enacted by Ali such as: Ali pretends as if he is lighting a fire (as he did on the day he and Münire were eloping) at the open-air cinema to menace Münire's father and brothers (who force her to marry with the son of the owner of the cinema); and during these moments, $A$ Long Story makes the filmgoers hear the sounds of the film (which used to be screening on the cinema Münire's father keeping), sounds of fire and the burning screen, sounds of the door Ali opened to enter the room of the projectionist, the fight Ali had with the projectionist and voices of Ali's speech which he made by the loudhailer he found in the projection room. In this way, the film chooses to show the real time (film's time) performance of Ali's enacting along with the sounds of past and this choice is made to make the filmgoer feel and re-think the significance of this past event in the entire film. This is the film's unique way probably to be more effective in the first time naive experience of a filmgoer, than to show him/her the past events happening in their own times. That is to say, the film does not prefer going back in its time and showing the events while they are happening, instead, it prefers bringing the past to little Mustafa's day by the play his parents perform and by the real sounds and voices of the past the film hears while Ali telling the story. In this way, it becomes clear that, what $A$ Long Story aims to do during these moments is to make little son admire his parents' story of elope and to make the filmgoers feel (re-think) that Mustafa will have the kind of events recurring in his own 'long story'. 


\section{This Study Re-thought}

This study re-thought $A$ Long Story as a 'being' that is able to 'think' in its own way. In accordance with this filmosophical perspective, this study tried to re-think a film through its own way of thinking 'recurrence' which is the 'whole knowledge' A Long Story keeps all the time in its filmind. At this point, it might be no wrong to say that this study occurred by taking its departure from Daniel Frampton's aim “to advance a new critical mode of attention" in film studies (Frampton 2006, p. 211).

This study re-thought A Long Story within the principals of Daniel Frampton's conception of 'filmosophy'. In this respect, it did not become a 'director-based writing'; did not 'theorise' the film via 'human thinking' and 'human-like terms'; did not 'separate form and content' of the film from each other whilst re-thinking it, instead felt the film as a 'whole being'; and did not 'employ' any 'technical terms' in its explanations or descriptions.

This study re-thought $A$ Long Story through the concept of 'recurrence' since the filmosopher felt at her 'first-time naive experience' of the film that A Long Story thinks itself recurring through its choices on waiting for the same train at its beginning and ending and on creation and employment of its characters, objects and places. It creates its characters (AliMustafa, Münire-Ayla) as having similar destinies; looking like each other (Münire-Ayla); thinking, reacting, deciding, speaking in similar ways (Ali-Mustafa, Münire-Ayla); and making the same utterances when they encounter similar conditions. A Long Story continues constructing itself upon the concept of 'recurrence' by the 'typewriter' (object) that changed hands between a father and a son to go on writing the same recurring story and by the small railway town, Doğançay (place) through which the film thinks itself starting again from where it seems to be ending.

CINEJ Cinema Journal: Recurrence: A Filmosophic Re-thinking of A Long Story/Uzun Hikaye

Volume 3.2 (2014) | ISSN 2158-8724 (online) | DOI 10.5195/cinej.2014.95 | http://cinej.pitt.edu 
This study re-thought $A$ Long Story through the 'moments' of play\&tale of Münire and Ali's elope during which the film thinks a unique way of bringing past to little Mustafa's present in order to impress him by his parents' backstory and make him learn what to do when he has the same kind of destiny they had. Additionally, A Long Story thinks these 'moments' of play\&tale as the precursor of the recurrence constructed intentionally in the entire film in various ways.

\section{REFERENCES}

Frampton, Daniel (2006). Filmosophy. Wallflower/Colombia University Press

\section{ENDNOTES:}


${ }^{1}$ This is the first and the last time that the name of the director of A Long Story is mentioned in this study since the conception of Filmosophy solely deals with a film itself not with its creator.

${ }^{2}$ We will see who can be named as a 'filmosopher' in the following pages.

${ }^{3}$ This study prefers to re-think a particular scene in relation to its significance in placing the concept of 'recurrence' into the entire $A$ Long Story, but whilst re-thinking, instead of naming it as a 'scene', it will accept and define it as the 'moments' - as some of the moments of the film's own life.

${ }^{4}$ By the way, another contrasting point between auteurist theories and filmosophy is, since filmosophy recommends keeping a creator/auteur out of mind while re-thinking a film, it deals with integrality in form and content of a 'single' film without giving any reference to the other films of its creator.

${ }^{5}$ Frampton understands this encounter as a "mix of thinkings": film's and filmgoer's (Frampton 2006, p. 162)

${ }^{6}$ Therefore, a filmgoer, who has a filmosophic perspective to be able to watch and re-think film as a unique "being' - "creating itself" by its own mind and way of thinking - independent from any other external effect, can be named as a filmosopher (ibid).

${ }^{7}$ In Frampton's words, "film-being is not human, and the film-world is not real. Film is its own reality, its own world, and the attention of any possible, conceptual film-being must be theorised as being part of that world, not separate and observational." (ibid)

${ }^{8}$ For Frampton, it is 'useless' to tell in a film writing how and with what technology someone made the film we see. Because, knowing 'how' "can make the reader/filmgoer forget to ask why the film did such-and-such." (Frampton 2006, p. 173)

${ }^{9}$ Despite this study is not willing to give place to any other knowledge external to A Long Story, it may be beneficial in some aspects to mention its subject shortly, as follows: "The film itself begins in the 1950s when Ali, now a young man, falls in love with Münire, the daughter of an open-air neighbourhood cinema in Eyup. In the peripatetic life he leads with Münire after eloping, Ali sets out to make a better place of every town they roll into. But his beaming, wide-eyed instinct for improving lives is matched by an irrepressible zeal for justice and equality; and the combination presents him with a new side of life at their every port of call. This LONG STORY of Ali, Münire and their son Mustafa drifting from one railway town to another through the 1960s and 1970s tells of an adventure that is by turns poignantly sad, rapturously upbeat and engagingly romantic..."

http://www.alongstoryfilm.com/

${ }^{10}$ In the context of this study, regarding the re-thinking process of $A$ Long Story, I name myself as a Filmosopher since Frampton attributes this concept to the filmgoer who is able to re-think a film from a filmosophical perspective.

${ }^{11}$ Apart from the 'long story' the film creates in its duration, it also provides us with the long/back story of Ali and Münire which they had before Mustafa's birth and this must be handled as the prologue of the 'story' film creates itself. By the way, the film gives the details of that 'backstory' in some particular 'moments' and those 'moments' will be re-thought in the last part of this study.

12 This study prefers employing the phrase 'the film' as the subject whilst writing about its technical features. Clearly, we can just see 'the film' moving or waiting, but no camera.

${ }^{13}$ The film shows the growing process of Mustafa by employing three Mustafas of different ages: pre-school age, secondary school age and graduated from the high school.

14 A Long Story thinks the recurrence in the destinies of two couples Ali-Münire and Mustafa-Ayla with almost 20 years gap between their generations.

${ }^{15}$ At the beginning, the film shows eldest Mustafa writing 'A Long Story' with a typewriter, but the film does not tell us who is he and where is he going by train. At the end, the film shows that Mustafa is not alone; writing with his typewriter (the long story the film thought/showed/told during its duration) whilst eloping with Ayla on the train approaching Dogancay.

${ }^{16}$ From the filmosophical perspective, films are already thinking/creating/telling themselves. However they can choose to be told by a character, voice, letter, diary and so on in their own ways. This is one of the intentional acts of a filmind. 